\title{
CORPORATE CERTIFICATES - NOW CONCLUSIVE
}

\author{
EUGENE MEEHAN*
}

A recent case from the Alberta Queen's Bench, Prim Investments Ltd. v. Madison Development Corporation Ltd. and Proskiw [1983] 1 W.W.R. 697, (1983) 23 Alta. L.R. (2d) 165 (Miller, J.) (hereinafter "Prim Investments") confirms the conclusiveness of corporate certificates in the Business Corporations Act S.A. 1981, c. B-15.

It was, and is, the practice of the Registrar of Corporations to antedate corporate certificates to the date of receipt of the appropriate documents in proper order. Both the Companies Act and Business Corporations Act deem the certificate of incorporation to be conclusive, ${ }^{1}$ but the Alberta Court of Appeal has interpreted the provision in the former Act not to be conclusive, only prima facie.

The following Court of Appeal decision is necessary background to introduce, and to appreciate, the significance of the recent Prim Investments case: C.P.W. Valve \& Instrument Ltd. v. Scott (1978) 84 D.L.R. (3d) 673, 3 B.L.R. 204, 8 A.R. 451, 5 Alta. L.R. (2d) 271 (hereinafter " $C . P . W$. Valve'). In C.P.W. Valve a Mr. Scott and a Mr. Vanderheyden (who may be treated as one and hereinafter referred to as "Scott") agreed to a sevenyear distribution contract with C.P.W. Valve, a manufacturer of industrial pressure gauges, whereby in the first year, prior to June 16, 1971, 5000 were to be purchased by Mr. Scott. By April of that year, only 1640 gauges of the total purchase commitment of 5000 had been purchased, which was pointed out in writing to Mr. Scott by C.P.W. Valve's solicitors, who also indicated a potential damages action for breach of contract. As the distribution contract had stated an intention on the part of Mr. Scott to incorporate a company to assume the distribution business, Mr. Scott on June 15 delivered to the Registrar the necessary and proper incorporating documents to incorporate a company by the name of S. \& V. Fluid Gauge Ltd., and placed an order on behalf of that company for the balance of the 5000 commitment. A certificate of incorporation was duly, and subsequently, issued by the Registrar, bearing the date of June 15, 1971. C.P.W. Valve rejected the order for the balance of the commitment as not being bona fide, and sued for breach of contract, the defendant alleging repudiation by counterclaim.

The learned trial judge ${ }^{2}$ refusing to admit evidence which, it was alleged, would indicate that S. \& V. Fluid Gauge Ltd. was not incorporated on June 15, held that sections 27 and 28 of the Companies Act governed:

27. A certificate of incorporation given by the Registrar in respect of a company is conclusive proof that all the requirements of this Act in respect of registration and of matters precedent and incidental to incorporation have been complied with, and that the company is a company authorized to be registered and duly registered under this Act.

28. From the date of incorporation mentioned in the certificate of incorporation the subscribers, together with the other persons that from time to time become members of the company, are a corporation by the name contained in the memorandum, capable of exercising all the

* LL.B., LL.M., LL.B. of the Faculty of Law, University of Alberta, and the Law Society of Alberta.

1. Companies Act R.S.A. 1980, c. C.20, ss. 27-28; Business Corporations Act S.A. 1981, c. B.15, s. 9 .

2. Moshansky, J., (1978) 8 A.R. 470, (1977) 1 B.L.R. 32 (Alta. S.C.T.D.). 
functions of an incorporated company, and having perpetual succession and a common seal, with power to hold land, but with such liability on the part of the members to contribute to the assets of the company in the event of its being wound up as is mentioned in this Act.

The Court of Appeal thought otherwise, and remitted the case back to the trial judge to hear the evidence, on the basis that inter alia, as the learned Mr. Justice Clement states: ${ }^{3}$

[the evidence] if admitted, would presumably have established that the certificate of incorpora. tion had not in fact been actually signed and sealed by the Registrar, nor given by him, until June 16th. Such evidence would enable C.P.W. to argue that S. \& V. Fluid Gauge Ltd. was not legally in existence at the time its purported purchase order was delivered, and that the subsequent issue of a certificate of incorporation dated June 15th had no effect in law on that state of affairs. ... [D]uring the whole of the time period of June 15th S. \& V. Fluid Gauge Ltd. had in fact no legal existence. . . . It follows that the purchase order purportedly given by S. \& V. Fluid Gauge Ltd. on that day had no legal validity at any moment of the critical period prior to June 16 th and cannot be relied on by Scott as performance of his obligation under the distributorship agreement. It existed only as a concept for which legal validity could only be secured by a statutory fiction reaching backwards to give legal substance and life to the concept. Section 28 may well have such effect for the purpose of the Act, particularly those mentioned in the section, but I would think it would take very clear words to enable a Court to say that the creation of status for a corporation can operate to negate a breach of contract that had already existed. . . .

Learned Mr. Justice McDermid dissented, emphasizing as follows: ${ }^{4}$

If the statute says a company is in existence at a certain date then, for all legal purposes relating to the status and capacity of that company, the company must be taken to be in existence. This artificial entity has only an existence in reality because the Legislature says it has and likewise, if the Legislature says it has an existence at a certain date, so it must have - it has an existence and it follows it must be able to contract. The Legislature has ordered a nunc pro tunc existence.

The Court of Appeal, being anxious to ensure that Mr. Scott not use a company to escape a personal obligation, assumed the evidence would show his company was incorporated after the June 15 deadline. Their ploy boomeranged however, for the evidence showed that in fact S. \& V. Fluid Gauge Ltd. was incorporated on June $15 .{ }^{5}$ Either the option of piercing the corporate veil or pre-incorporation contracts could have been safely used to pin personal liability on Scott. As it was, Scott escaped Scot free. ${ }^{6}$

This decision, and its consequences, have been previously reviewed elsewhere by this writer, ${ }^{7}$ but the negative aspects of this decision may be briefly noted as follows: to misconstrue the clear wording of a statute in order to interpret "conclusive proof" as effectively being "prima facie proof" is to frustrate an unequivocally delineated legislative intent; the public policy of the statute is to avoid exactly this situation, controverted examinations of the exact date of incorporation; by virtue of the administrative assistance of the statute, incorporation is a one-step yes-or-no

3. (1978) 84 D.L.R. (3d) 673 at 681-685. Concurred in by the learned Mr. Justice Lieberman.

4. Id. at 678.

5. (1979) 9 Alta. L.R. (2d) 35 (Alta. S.C.T.D.).

6. A further appeal was taken to the Court of Appeal, but dismissed without reasons, Feb. 7,1980 . Interestingly, and contradictorily, the same appellate bench as in C.P.W. Valve (Mr. Justices Clement, Lieberman and McDermid) held in Re Medicine Hat Greenhouses Ltd. and German and The Queen (No. 3) (1979) 45 C.C.C. (2d) 27 that a ministerial certificate deemed by the Income Tax Act to be "conclusive evidence" was indeed "conclusive evidence". (Leave to appeal to the Supreme Court of Canada refused, Feb. 5, 1979.).

7. E. Meehan, "Evidential Controvertibility of Canadian Company Law 'Conclusive Proof' ", (1980) 130 New Law Jo. 1075. See also K. Ferguson, J. McCormick, E. Meehan, and S. Principi, Alberta Corporations Law Guide (1983) Incorporation tab (in press). 
proposition, not a whimsical discussion as to whether it was incorporated for one purpose yet not for others; the law should encourage the stability and security of business transactions amongst lay persons by affirming that when an official certificate plainly states a specified company is incorporated on a specified date that it is indeed so - particularly when a statute says that that certificate is conclusive proof of what is stated therein.

The new Business Corporations Act sets out to tackle the problem with the following provision, the drafting of which is a direct, and literal, response to the comments of learned Mr. Justice Clement in C.P.W. Valve: $^{\mathrm{B}}$

9(1) A corporation comes into existence on the date shown on the certificate of incorporation.

(2) A certificate of incorporation is conclusive proof for the purposes of this Act and for all other purposes

(a) that the provisions of this Act in respect of incorporation and all requirements precedent and incidental to incorporation have been complied with, and

(b) that the corporation has been incorporated under this Act as of the date shown in the certificate of incorporation.

The section worked, as the Prim Investments case now shows. The facts, briefly, are as follows: Madison Development Corporation Ltd. (hereinafter "Madison") was registered as a (public) company under the Companies Act. To facilitate the mandatory continuation procedure, the Registrar had sent out blank articles of continuance forms to all companies for completion and registration. An employee at Madison, thinking these forms to be routine corporate information questionnaires, filled them out and had the President sign them. Et voila, Madison was now continued under the new Act. The no small matter of a pre-continuation shareholders' meeting as required by s. 261(4),(6) of the new Act had of course not been held. What to do? One of the shareholders, Prim Investments Ltd., brought application for a declaration that there never having been a shareholders' meeting, the certificate of continuance was null and void and must be cancelled. It might here be noted that s. 181(5) of the new Act deems the certificate of continuance to be the certificate of incorporation of the continued corporation, which brings the remedial s. 9 into play.

The learned Mr. Justice Miller, after reviewing the jurisprudential and statutory background in England and Canada to $\mathrm{s} .9$ of the new Act, ${ }^{9}$ held as follows: ${ }^{10}$

Clement J.A. [in C.P.W. Valve] stated ... that it would take 'very clear words' to make the certificate conclusive proof of the date of incorporation for purposes other than those of the Act. It is my view that those very clear words have been supplied by s. 9 of the new legislation. Indeed, it is difficult to see how the intention of the legislators could have been more clearly expressed.

... it would follow ... that the problems raised by ...C.P.W. Valve ... are no longer applicable in Alberta under the new Act and they may be quietly laid to rest.

... It would follow logically that, for all purposes, the said certificate can be relied upon by third parties to be conclusive proof of Madison's continued status under the Business Corporations Act and there is no need for that company to do anything further to perfect its status.

This is a commonsense result. The Institute of Law Research and Reform, ${ }^{11}$ and Mr. Justice Miller, are to be commended for, respectively,

8. Supra n. 1. Emphasis added.

9. See also Meehan, supra n. 7 at 1075-1076.

10. [1983] 1 W.W.R. 697 at 710, (1983) 23 Alta. L.R. (2d) 165 at 176-177.

11. In particular the Institute's Company Law Project Director, Mr. George Field, Q.C., and the Director of the Institute, Mr. Bill Hurlburt, Q.C. 
their clear drafting, and straightforward interpretation.

The decision, though strictly restricted to certificates of incorporation and continuance, also affects other certificates issued under the new Act, being certificates of amalgamation, ${ }^{12}$ certificates of amendment, ${ }^{13}$ certificates of discontinuance, ${ }^{14}$ certificates of dissolution, ${ }^{15}$ certificates of intent to dissolve,${ }^{16}$ certificates of revocation of intent to dissolve,${ }^{17}$ certificates of (extra-provincial) registration, ${ }^{18}$ certificates of registration of amalgamating (extra-provincial) corporations, ${ }^{19}$ certificates of registration of restated articles of incorporation, ${ }^{20}$ and certificates of revival..$^{21}$ The practice of antedating certificates has also now been legislatively validated by $\mathrm{s}$. $255(3),{ }^{22}$ though this was not mentioned by the learned Mr. Justice Miller. ${ }^{23}$

The unfortunate query, however, is - does s. 9 go too far? Was too good a job done? The Institute of Law Research and Reform concedes that "the Registrar would have the legal power to antedate his certificate to a date before he receives incorporating documents (or even to issue a certificate without any supporting documents)." ${ }^{24}$ What if the lawyer is possessed of the necessary incorporating documents (as well as the registration fee and his professional fee) but negligently omits to file the documents at the appropriate government office, or indeed any office? ${ }^{25}$ What if the signatories are all infants, ${ }^{26}$ or all mental incompetents? ${ }^{27}$ What if a signatory subsequently attempts to repudiate the signature on the basis of fraud,

12. Business Corporations Act, S.A. 1981, c. B-15, ss. 180, 249(2).

13. Id., ss. 13, 249(2) (amendment re name); ss. 27(6),(7), 255, 249(2) (amendment re series of shares); ss. 171, 172, 173(1), 255, 249(2) (amendment re fundamental change); ss. $185(5),(6), 255,249(2)$ (amendment re reorganization); ss. 186(11),(12), 255, 249(2) (amendment re arrangement); ss. 276(4), 249(2) (amendment re extra-provincial corporation).

14. Id., ss. 182(6),(7), 255, 249(2).

15. Id. ss. 203(5), $255,249(2)$; ss. 204(5),(15), 249(2); ss. 205(1),(3),(4), 249(2); s. 206(4)(a); s. 216(5).(8); s. 261(15).

16. Id., ss. 204(5),(6), 255.

17. Id., ss. 204(11),(12), 255.

18. Id., ss. $271(2), 255,249(2)$.

19. Id., ss. 277.

20. Id., ss. $174(3),(4), 255,249(2)$.

21. Id., ss. 201(3),(4), 249(2).

22. "A certificate referred to in subsection (2) issued by the Registrar may be dated as of the day he receives the articles [widely defined in s. 1(b.1)], statement or Court order pursuant to which the certificate is issued or as of any later day specified by the Court or person who signed the articles or statement."

23. With regard to an error in a certificate, see s. 258. Certificates are to be signed by the Registrar or his agent, though that 'signature' may be printed or otherwise mechanically reproduced: ss. $249(1), 255(4)$.

24. "Proposals For a New Alberta Business Corporations Act", Vol. 1, Report No. 36, 14 (1980, Institute of Law Research and Reform, Edmonton, Alberta). See for example Frawley v. Tenafly Transport Co. (1921) 95 N.J.L. 405, 113 A. 242 (Ct. of Err. and Apps. of N.J.), where passengers injured in a bus were allowed to sue the transportation company as a corporation even though its articles were not filed until four days after the date of the accident.

25. Cranson v. I.B.M. Corp. (1964) 234 Md. 477,200 A. 2d 33 (Ct. of Appeals of Md.). See also Birt v. St. Mary Mercy Hospital of Gary, Inc. (1978) 370 N.E. 2d 379 (Dist. Ct. of Appeals of Ind.); Baker v. Bates Street Shirt Co. (1925) 6 F. 2d 854 (U.S. Circ. Ct. of Appeals); Bergeron v. Hobbs (1897) 96 Wis. 641, 71 N.W. 1056 (Sup. Ct. of Wis.).

26. Re Laxon \& Co. (No. 2) [1892] 3 Ch. 555 (Ch. D.); Thies v. Weible (1934) 254 N.W. 420 (Sup. Ct. of Neb.). 
mistake, or misrepresentation ${ }^{28}$ What if another statute prohibits a particular type of enterprise or activity being incorporated?" These "what if 's" have occurred in reported decisions; other possibilities are only limited, or otherwise, by human ingenuity and chance. The danger is the unwitting though potential codification of the much maligned American "de facto incorporation" or "estoppel incorporation" doctrines. ${ }^{30}$

Whether s. 9 goes too far is essentially a value-judgment based on one's idea of the balance between the conclusiveness of an official certificate and the reality behind it. As always with new legislation, time will tell.

27. Infants and mental incompetents are not precluded from incorporating corporations by the Business Corporations Act (ss. 5, 1(m)), but are precluded from being directors ( $\mathrm{s}$. $100(1))$. This is indeed curious, as the Act permits the infant and mentally incompetent shareholders to abrogate, and take for themselves, all powers of the sui juris directors (s. 140(1)(c)).

28. Re Metal Constituents Ltd., Lord Lurgan's Case [1902] $1 \mathrm{Ch} .707$ (Ch. D.). Section 206(1)(c) of the Act permits application to the Court for dissolution of the corporation if any certificate is procured by misrepresentation.

29. Edinburgh and District Aerated Water Manufacturers Defence Association v. Jenkinson (1903) 5 F. 1159 (Scottish Ct. of Sess.); British Association of Glass Bottle Manufacturers v. Nettlefold (1911) 27 T.L.R. 527 (K.B. Div.).

30. A.H. Frey, "Legal Analysis and the 'De Facto' Doctrine", (1952) 100 U. Penn. L.R. 1153; E.M. Dodd Jr., "Partnership Liability of Stockholders in Defective Corporations", (1927) 40 Harv. L.R. 521; C.J.C. Jr., "Defective Formation and Suits in the Corporate Name", (1936) 84 U. Penn. L.R. 514. 